\section{Roman Bihun, Vasyl Lytvyn, Nazar Oleksiv}

\title{
MATHEMATICAL MODELING AND ANALYSIS OF THE DEVELOPMENT OF TERRITORIAL COMMUNITIES
}

This article examines the problems of the development of united territorial communities, in particular, unemployment and economic problems. The object of the research is the improvement of territorial communities on the example of the Lviv region (Ukraine). One of the most problematic areas is the fact that communities, in most cases, do not have enough funds to solve economic and other problems.

The study uses the idea of the need to create self-sufficient communities with a sufficient number of financial instruments for their own development. The mathematical model of the decision support system for the development of territorial communities using the agro-industrial sector is also considered. An important step in building a mathematical model of the agro-industrial complex is taking into account the specifics of agriculture. The paper considers a mathematical model of linear and multifactorial regression, which describes the relationship between the amount of resources expended and the volume of output. Since the processes in the economy and production processes in agriculture are complex, it is difficult to describe them using only linear deterministic models. A common case is when task variables take some discrete values or values from a specific one. This situation makes the search difficult. To build a mathematical model for the development of territorial communities and study the fact that the development of agro-industry will improve the overall economic situation of the territorial community, correlation and regression analysis, the Farrar-Glauber method and the method of least squares are used. Thanks to the listed instruments, the statement is formed that the regulation of key factors of economic indicators of the agricultural sector can positively affect the growth of the economic component of territorial communities. The created mathematical model clearly forms the conclusion that agriculture in local communities can become an economic engine of community development, taking into account regional conditions.

Keywords: territorial community, mathematical model of the agro-industrial complex, decision support systems, correlation-regression analysis.

Bihun, R., Lytoyn, V., Oleksiv, N. (2021). Mathematical modeling and analysis of the development of territorial communities. Technology Audit and Production Reserves, 3 (2 (59)), 6-12. doi: http://doi.org/10.15587/2706-5448.2021.232788

\section{Introduction}

Today, a number of countries are in the stage of profound changes in the system of regulation of public relations. In terms of prospects for local development, decentralization has emerged as an effective way to change the essential characteristics of society. The experience of developed countries shows that the main prerequisite for the successful development of communities is the unification of territories and resources, in which the state creates the necessary conditions for the development of communities, and they themselves must choose the priorities that they need. Therefore, for each community, the question arises, «Which sector of industry from the available resources can bring the most benefit to society?»

Let's consider this issue on the example of the development of territorial communities of Ukraine, since in Ukraine there is also a tendency towards decentralization of power and the unification of several settlements, thus forming a capable territorial community. This approach to the formation of territorial communities by combining territories and resources is supported by the law of Ukraine «On the voluntary unification of territorial communities», which provides for a significant reform of local self-government [1]. The aim of the reform is to provide communities with the opportunity to themselves, at the expense of their own resources, to ensure the livelihood and ability of their territories, as well as quality services for their residents.

Today, such social problems of the countryside as unemployment, poverty and forced labor migration, the decline of social infrastructure, the demographic crisis and the degradation of the rural settlement network, and the like, are aggravated. The main reasons for this are the authorities' ignorance of the need for progressive changes in the management of the development of rural areas, and disregard of public opinion and the problems of land owners. For the normalization of work, the possibility of solving various economic problems by the community on its own 
and for the further development of territorial communities, an important condition is the involvement of scientific approaches, namely the development of mathematical models for the development of such communities.

Agro-industrial production, subject to effective development, is one of the key links to ensure the economic security and stability of the country. Therefore, it is assumed that agro-industry can also be a key link in the development of territorial communities, since the modernity of the Ukrainian economy recognizes the agricultural sector as an important structural element of development.

Ukraine occupies a territory with a unique combination of natural and climatic conditions and geostrategic position. This is what provides the agricultural sector of the state with the opportunity to occupy an important place in the international food market and make a significant contribution to the socio-economic life of the country. And the present agro-industry of Ukraine clearly defines a number of unresolved issues and tasks generated by the existing negative phenomena. The general process of solving such problems of the agroindustry requires considering the agroindustrial complex as a complex multistructural composition. It is this view of the agricultural sector that highlights the need to rationalize and reorganize the structural elements of the complex itself. In addition, such additional elements of the complex also require constructive changes; they also determine the course of development of the agricultural industry: the introduction of new technologies, the optimization of the use of financial, material and labor flows.

\section{The object of research and its technological audit}

The object of research is the improvement of territorial communities on the example of the Lviv region (Ukraine). The subject of the research is the mathematical model of the development of the united territorial communities (UTG).

UTGs of Lviv region consists of 7 districts (Chervonohrad, Zolochiv, Lviv, Drohobych, Yavorivs, Sambir and Stryi), which include 73 territorial communities. During JanuaryMay 2020, receipts to the general fund of the budgets of all UTGs of the region amounted to 19.25 million USD. The average income per capita during this time was slightly more than 55.2 USD. The Slavske community has the best economic indicators - more taxes are collected on its territory, and more budget money is spent per capita. But the worst indicators are in the Volia-Baranetska UTG, located in the Sambir district. It should be noted that the high performance of the Slavske UTG, which includes Slavske and eight surrounding villages, can be explained by the fact that the main taxpayer to the community budget is OKKO, one of the largest networks of petrol stations in Ukraine. At the same time, many communities do not have enough money to live, including the deficit in the budgets of six UTGs. The situation remains difficult, despite a $52 \%$ decrease in the share of the deficit since the beginning of the year. Thus, the lack of a monthly wage fund in the budgets of the Radekhiv UTG was $60 \%$, Nove Misto - $148.9 \%$, Nyzhankovychi - $124.9 \%$.

\section{The aim and objectives of research}

The aim of research is to build a mathematical model for the development of territorial communities. This will help create better conditions for economic growth and better quality of life for the public.

To achieve the aim, the research process is divided into the following steps:

1. Select and substantiate a mathematical apparatus that allows for a comprehensive analysis of the impact of the development of the agro-industrial sector on the general economic situation of the territorial community.

2. Examine the conclusion obtained by substituting real data of the agro-industrial sector into the constructed model.

\section{Research of existing solutions to the problem}

Many sociologists, economists, political scientists and many other scientists have studied the development of territorial communities in their scientific works. Over the past decade, a number of works have been devoted to solving this problem based on the construction of efficient algorithms using natural systems (swarm algorithms, etc.) for various applied problems. In particular, in [2], the graph partitioning problem is used to construct balanced trees. Such mathematical models are also used for clustering problems in [3].

The authors of the work [4] show that modern Ukrainian approaches to storage, rational use and building up of their own resource potential of the territorial community encompass the best world achievements and their own developments over the years of independence. However, there remains unlimited scope for scientific research on the problem of conservation, rational use and building up the resource potential of society, which will answer many existing questions, in particular, concerning its environmental safety.

In work [5], the essence of financial decentralization is studied, the advantages and disadvantages of its functioning are indicated. The features of the formation of the revenue side of local budgets in the context of decentralization at the expense of tax and non-tax revenues and other revenues (excluding interbudgetary transfers) are revealed. And in [6], the issues of financial incentives for the development of united territorial communities in the context of the continuation of the decentralization reform are considered. The role of the financial and budgetary component of decentralization of management is shown at the local level. The individual indicators of the implementation of local budgets of the united territorial communities in all regions of Ukraine are analyzed. The conditions for the effective implementation of their own and delegated powers by local self-government bodies have been formed.

For the successful development of the regions, certainty and the presence of consolidating ideas about the future are needed. These are important needs of business and society, which are met through the mechanism of territorial socio-economic planning, primarily strategic planning. In work [7], the concepts of strategic management are considered, the differences between strategic and current management are described using the example of management of sectors of the social block. Also, the essence of management of the territorial economy of the region, as well as the issues of the implementation of life support and social services for the population, the improvement of the territorial economy as a whole, the acquisition of new qualitative characteristics of a higher level. 
Using the example of Latvia, the author of [8] analyzed the structural scheme for assessing the territorial state of development, developed earlier, assessing the territorial state of development of the statistical regions of the country. The analysis showed that it is impossible to draw unambiguous conclusions regarding the level of their development, since each region of Latvia has its own quality or essence of development.

Scientific works in $[9,10]$ reveal a wide range of issues, including studies of the essence of the concept of «decentralization of public power», its types and forms, implementation principles, assessment of decentralization models, reform implementation algorithm, and the like. Thus, work [11] is aimed at a comparative analysis of the development and current state of reforms of state and local government in France and Germany. At the same time, some issues remain unresolved both in theoretical and methodological aspects, and therefore necessitate further research and search for ways to solve problems in this area of activity.

Thus, the results of the analysis allow to conclude that the development of territorial communities is quite an important topic. This will make it possible to better form local budgets and improve the country's economy.

\section{Methods of research}

In the course of the study, a correlation-regression analysis was carried out, which expresses the dependence of the resulting indicator on several key factors and allows us to assess the density of the relationship between these factors. During the analysis, data were collected, the model was built, and the model was analyzed and evaluated. In order to identify the relationship between the selected factors in the regression model, we used the Farrar-Glauber method. After the multicollinearity was investigated and the multiple regression equation was obtained, the least squares method was applied to determine the vector of estimates of the regression coefficients.

\section{Research results}

To consider modeling as one of the ways to solve a number of agro-industrial problems, it is necessary to take into account the peculiarities of the functioning of agriculture, since it is these features that determine the future specificity of the model solution to the problem. The construction of any economic and mathematical model necessarily takes into account the following key elements:

- characteristics of externally variable;

- set of internal parameters that are taken into account and can, in accordance with the purpose of modeling, characterize a particular economic process;

- parameters or characteristics of the process to be obtained.

The construction of models by specialists differs in approaches and different sets of defining parameters. In modeling, agriculture is guided by a systematic approach, taking into account not only individual components and their interrelationships, but also the system as a whole. It is necessary to take into account that agriculture is an open system, therefore, when modeling it, it is necessary to observe a systematic approach, considering not only individual components and their interrelationships, but also the entire system as a whole. For a system that is defined as an object of holistic education, the goal and conditions of its functioning are determined. This is what prompts specialists to consider modeling the activities of enterprises in the agro-industrial complex as modeling business processes in a competitive environment, which are rapidly changing under the influence of a large number of both internal and external factors. Such components as the development, economic and implementation of flexible, adaptive to external conditions of control systems for such a process are proposed to be carried out using modern technologies, based on the methods of system analysis and informatization. The main goal of the system provides for finding benefits (most often profit), which is needed to maintain both simple and extended reproduction of food products and agricultural raw materials, as well as the development of territorial communities.

To begin with, we highlight the key factors affecting the development of agriculture. It must be remembered that these factors must be in causal relationships with the indicator under study. These factors must demonstrate the impact on the studied indicator and have a quantitative assessment. A desirable condition is the fact that these factors do not overlap with certain factors, that is, do not have interrelationships [12].

The classical factors of production are labor (purposeful human activity), land (natural resources) and capital. Also, in the course of the study, an additional indicator was involved - the infrastructure, which determines the level of transport communications for the delivery of products to the end user.

It was decided to choose agricultural products at constant prices as the resulting indicator. Actually, agricultural products are the result of activities, which includes crop and livestock products intended for sale, processing or onfarm consumption. This indicator is quite objective, since from a material point of view, it allows you to summarize the result of the yield during the calendar year.

The next step in the correlation and regression analysis is to build a system of the studied indicators, shown in Table 1.

Table 1 mixes in itself statistical data on the development of agriculture in the Lviv region in the period from 2010-2019, which demonstrate the resulting and factor indicators. The information base for the current analysis was statistical data published on the web resources of the State Statistics Service of Ukraine and the Main Department of Statistics in the Lviv region [13, 14]. During the study of the Lviv region, information was used in the range of 2010 and 2019. According to the Table 1 it is possible to see the growth of indicators of rural production in the Lviv region. The annual increase in the resulting factor proves the prospects for the development of agriculture in the region under study.

Let's build a correlation matrix and determine the degree of influence of factors on the resulting factor. For this, let's use the correlation matrix $R_{y}$ :

$$
R_{y}=\left(\begin{array}{cccc}
1 & r_{12} & \ldots & r_{1 n} \\
r_{21} & 1 & & r_{2 n} \\
\ldots & \ldots & \cdots & \ldots \\
r_{n 1} & r_{n 2} & \cdots & 1
\end{array}\right),
$$

where $r_{j k}-$ correlation coefficient, which is calculated using the formula: 


$$
r_{j k}=\frac{\sum_{i=1}^{n}\left(x_{i j}-\overline{x_{j}}\right)\left(x_{i k}-\overline{x_{k}}\right)}{\sqrt{\sum_{i=1}^{n}\left(x_{i j}-\overline{x_{j}}\right)^{2} \sum_{i=1}^{n}\left(x_{i k}-\overline{x_{k}}\right)^{2}}},(j, k=1,2, \ldots n),
$$

where $n$ - sample size; $\bar{x}, \bar{y}$ - sample means, which are determined as follows:

$$
\begin{aligned}
& \bar{x}=\frac{1}{n} \sum_{i=1}^{n} x_{i}, \\
& \bar{y}=\frac{1}{n} \sum_{i=1}^{n} y_{i} .
\end{aligned}
$$

Using the statistics from Table 1, let's construct the correlation matrix $R_{y}$, which is presented in Table 2 .

Based on the Table 2, it can be concluded that the variables are included in the regression model. If the value of the coefficient is not indicated, it means that the relationship between this factor and the effective variable is either very weak or absent at all, so the factor can be excluded from the model. Therefore, we see that there is a very strong relationship between the resulting factor and the sown area $(0.950)$, since $|r|>0.9$. There is a strong relationship between labor productivity (0.851), investment $(0.836)$, return on investment $(0.789)$, transportation of goods (0.785) and the key factor, since $|r|>0.7$.

At the same time, there is an average relationship between agricultural production and productivity (0.563), sales costs $(0.640)$, since $0.3 \leq|r| \leq 0.7$. And between the resulting indicator and the number of employees (0.086), there is practically no connection. So, it is possible to make a decision to exclude factors between which there is a weak connection in further analysis.

The final form of partial correlation coefficients is shown in Table 3.

In order to identify the relationship between the selected factors in the regression model, we use the FarrarGlauber algorithm. Collinearity checking with this test involves several steps.

\begin{tabular}{|c|c|c|c|c|c|c|c|c|c|}
\hline \multirow{4}{*}{$\begin{array}{l}\text { Reporting } \\
\text { period }\end{array}$} & \multirow{3}{*}{$\begin{array}{c}\begin{array}{c}\text { Resultant } \\
\text { indicator }\end{array} \\
\begin{array}{c}\text { Agricultural } \\
\text { products }\end{array}\end{array}$} & \multicolumn{8}{|c|}{ Factor of production } \\
\hline & & \multicolumn{2}{|c|}{ Work } & \multicolumn{2}{|c|}{ Land } & \multicolumn{2}{|c|}{ Capital } & \multicolumn{2}{|c|}{ Infrastructure } \\
\hline & & $\begin{array}{l}\text { Number of } \\
\text { employed }\end{array}$ & $\begin{array}{c}\text { Labor } \\
\text { productivity }\end{array}$ & Sown area & Yield & Investment & $\begin{array}{l}\text { Return on } \\
\text { investment }\end{array}$ & $\begin{array}{l}\text { Carriage } \\
\text { of goods }\end{array}$ & $\begin{array}{c}\text { Sales } \\
\text { expenses }\end{array}$ \\
\hline & Million USD & $\begin{array}{l}\text { Thousand } \\
\text { people }\end{array}$ & $\begin{array}{l}\text { Million USD/ } \\
\text { thousand people }\end{array}$ & Thousand ha & $\begin{array}{l}\text { Million USD/ } \\
\text { thousand ha }\end{array}$ & Million USD & Million USD & $\begin{array}{l}\text { Carriage of } \\
\text { goods }\end{array}$ & $\begin{array}{l}\text { Million USD/ } \\
\text { thousand ton }\end{array}$ \\
\hline 2010 & 599.91 & 176.30 & 3.40 & 540.90 & 1.11 & 319.82 & 0.53 & 23283.00 & 0.03 \\
\hline 2011 & 682.89 & 204.30 & 3.34 & 563.40 & 1.21 & 438.75 & 0.64 & 25697.20 & 0.03 \\
\hline 2012 & 712.98 & 205.10 & 3.48 & 596.90 & 1.19 & 404.68 & 0.57 & 26507.10 & 0.03 \\
\hline 2013 & 715.80 & 219.40 & 3.26 & 621.00 & 1.15 & 355.55 & 0.50 & 24585.80 & 0.03 \\
\hline 2014 & 755.84 & 189.20 & 3.99 & 628.70 & 1.20 & 346.07 & 0.46 & 24456.50 & 0.03 \\
\hline 2015 & 732.97 & 184.00 & 3.98 & 638.30 & 1.15 & 484.84 & 0.66 & 24422.20 & 0.03 \\
\hline 2016 & 751.21 & 191.50 & 3.92 & 662.00 & 1.13 & 673.86 & 0.90 & 25152.50 & 0.03 \\
\hline 2017 & 797.87 & 191.50 & 4.17 & 679.80 & 1.17 & 873.09 & 1.09 & 27223.10 & 0.03 \\
\hline 2018 & 826.47 & 194.80 & 4.24 & 674.90 & 1.22 & 1050.18 & 1.27 & 29599.30 & 0.03 \\
\hline 2019 & 833.19 & 191.80 & 4.34 & 698.40 & 1.19 & 1125.01 & 1.35 & 27761.70 & 0.03 \\
\hline
\end{tabular}

Table 1

Indicators of agricultural factors for correlation and regression analysis (2010-2019)

Correlation matrix $B_{y}$

\begin{tabular}{|c|c|c|c|c|c|c|c|c|c|}
\hline $\begin{array}{c}\text { Resulting indicator/ } \\
\text { production factor }\end{array}$ & $\begin{array}{c}\text { Agricultural } \\
\text { products }\end{array}$ & $\begin{array}{c}\text { Number of } \\
\text { employed }\end{array}$ & $\begin{array}{c}\text { Labor pro- } \\
\text { ductivity }\end{array}$ & Sown area & Yield & Investments & $\begin{array}{c}\text { Return on } \\
\text { investment }\end{array}$ & $\begin{array}{c}\text { Cargo trans- } \\
\text { portation }\end{array}$ & $\begin{array}{c}\text { Sales } \\
\text { expenses }\end{array}$ \\
\hline Agricultural products & 1.000 & - & - & - & - & - & - & - & - \\
\hline Number of employed & 0.086 & 1.000 & - & - & - & - & - & - & - \\
\hline Labor productivity & 0.851 & -0.450 & 1.000 & - & - & - & - & - & - \\
\hline Sown area & 0.950 & -0.019 & 0.865 & 1.000 & - & - & - & - & - \\
\hline Yield & 0.563 & 0.355 & 0.308 & 0.279 & 1.000 & - & - & - & - \\
\hline Investments & 0.836 & -0.133 & 0.812 & 0.820 & 0.380 & 1.000 & - & - & - \\
\hline Return on investment & 0.789 & -0.164 & 0.785 & 0.782 & 0.335 & 0.996 & 1.000 & - & - \\
\hline Cargo transportation & 0.785 & 0.178 & 0.596 & 0.639 & 0.707 & 0.851 & 0.834 & 1.000 & - \\
\hline Sales expenses & 0.640 & -0.056 & 0.619 & 0.733 & 0.055 & 0.272 & 0.215 & 0.028 & 1.000 \\
\hline
\end{tabular}


Table 3

Partial correlation coefficients

\begin{tabular}{|c|c|c|c|c|c|c|}
\hline \multicolumn{7}{|c|}{ Production factors } \\
\hline 1 & 1 & 3 & 4 & 6 & 7 & 8 \\
\hline 1 & 1 & 0.851 & 0.950 & 0.836 & 0.789 & 0.785 \\
\hline 3 & $\mathrm{X}$ & 1 & 0.865 & 0.812 & 0.785 & 0.596 \\
\hline 4 & $\mathrm{X}$ & $\mathrm{X}$ & 1 & 0.820 & 0.782 & 0.639 \\
\hline 6 & $\mathrm{X}$ & $\mathrm{X}$ & $\mathrm{X}$ & 1 & 0.996 & 0.851 \\
\hline 7 & $\mathrm{X}$ & $\mathrm{X}$ & $\mathrm{X}$ & $\mathrm{X}$ & 1 & 0.834 \\
\hline 8 & $\mathrm{X}$ & $\mathrm{X}$ & $\mathrm{X}$ & $\mathrm{X}$ & $\mathrm{X}$ & 1 \\
\hline
\end{tabular}

Let's check the entire array of factors using the following formula [15]:

$$
X_{p}^{2}=-\left(n-1-\frac{2 m+5}{6}\right) \ln (\operatorname{det} R),
$$

where $n$ - sample size; $m$ - the number of factors of production; $\operatorname{det} R$ - determinant of the correlation matrix; $R$ - correlation matrix of the form:

$$
R=\left[\begin{array}{cccc}
1 & r_{12} & \ldots & r_{1 n} \\
r_{21} & 1 & & r_{2 n} \\
\cdots & \ldots & \cdots & \cdots \\
r_{n 1} & r_{n 2} & \cdots & 1
\end{array}\right] .
$$

Let's determine the value $X_{p}^{2}$ for this study using the formula (5). Substituting the data into the formula, let's obtain:

$$
X_{p}^{2}=-\left(10-1-\frac{2 \cdot 5+5}{6}\right) \ln (1.0 e-6)=89.8 \text {. }
$$

Comparing the calculated value with the tabular value is 18.3 , let's conclude that there is multicollinearity in the vector of factors, since $X_{p}^{2}>X_{B}^{2}$.

Let's compose a multiple regression equation in the form:

$$
Y=f(\beta, X)+\varepsilon,
$$

where $\beta$ - vector of parameters; $X=X\left(X_{1}, X_{2}, \ldots, X_{m}\right)_{1}-$ vector of independent variables; $\varepsilon$ - deviation; $Y$ - resulting variable. The theoretical linear multiple regression equation is:

$$
Y=\beta_{0}+\beta_{1} X_{1}+\beta_{2} X_{2}+\ldots+\beta_{m} X_{m}+\varepsilon
$$

In the empirical equation $\beta_{0}$ is a free term that determines $Y$ in the case when the other variables are equal to zero.

Let us define the vector of estimates of the regression coefficients. Let's use the method of least squares. This method is considered the most common and theoretically sound. Estimates of the regression coefficients found by this method under certain assumptions have a number of optimal properties (unbiasedness, efficiency, validity) [16, 17]. The vector of coefficients is formed by the formula:

$$
S=\left(X^{T} X\right)^{-1} X^{T} Y .
$$

After multiplying the matrices and finding the inverse matrix to the resulting one, let's obtain a vector of estimates of the regression coefficients, which equal to:
$\beta_{0}=-75.9$
$\beta_{1}=16.6$;
$\beta_{2}=0.8$
$\beta_{3}=0.5$;
$\beta_{4}=-455.4$
$\beta_{5}=0$.

Mathematical model using regression coefficients:

$$
Y=-75.9+16.6 X_{1}+0.8 X_{2}+0.5 X_{3}-455.4 X_{4} \text {. }
$$

From this model, it is possible to draw an economic conclusion that there is a directly proportional relationship between the factors $X_{1}, X_{2}, X_{3}, X_{5}$, therefore:

- an increase in the indicator $X_{1}$ (labor productivity) per unit affects an increase in $Y$ by an average of 16.6 ;

- an increase in the $X_{2}$ index (sown area) per unit affects an increase in $Y$ by an average of 0.8 ;

- an increase in $X_{3}$ (investment) per unit leads to an increase in $Y$ by an average of 0.5 units;

- an increase in the factor $X_{5}$ (transportation of goods) per unit does not lead to a significant increase in $Y$.

An inverse relationship exists for the $X_{4}$ indicator (return on investment). Therefore, an increase in this indicator $X_{4}$ by one leads to a decrease in the key factor $Y$ by an average of 455.34 units.

To objectively assess the closeness of relationships between factors and indicators, we calculate the coefficient of determination using the formula:

$$
R^{2}=1-\frac{\varepsilon^{2}}{\sum_{i=1}^{n}\left(y_{i}-\bar{y}\right)^{2}} .
$$

For this case, the coefficient of determination is equal to:

$$
R^{2}=1-\frac{590.23}{44129.92}=0.99 \text {. }
$$

Therefore, it is possible to conclude that there is a close relationship between the resulting indicator and the factors that directly affect its formation. This conclusion is made because it is $R^{2}$ as close to one as possible, which will positively affect the approximation of empirical data and bring the observation points directly to the regression line.

When assessing the adequacy of the model, let's use the Fisher criterion:

$$
F_{p}=\frac{R^{2}}{1-R^{2}} \cdot \frac{n-m-1}{m},
$$

where $m$ - the number of factors on which y depends; $n$ - the number of observations.

Calculation of the value $F_{p}$ :

$$
F_{p}=\frac{0.9867}{1-0.9867} \cdot \frac{10-5-1}{5}=59.3 .
$$

Let's find the tabular value of $F$, after calculating the number of degrees of freedom, which are $k_{1}=m=5$ and $k_{2}=n-m-1=10-5-1=4$. Then, $F_{k p}(5 ; 4)=6.26$. Since $F_{p}>F_{k p}$, it can be argued that the coefficient of determination is statistically significant and the regression equation is reliable. 
The next step is to analyze the parameters of the regression equation. Let's move on to the statistical analysis of the obtained regression equation: checking the significance of the equation and its coefficients, studying the absolute and relative errors of approximation. Interim data for identifying the adequacy of the model are presented in Table 4.

Table 4

The value of intermediate indicators to determine the adequacy of the model

\begin{tabular}{|c|c|c|c|c|c|}
\hline $\begin{array}{c}\text { The value of the } \\
\text { resulting indicator }\end{array}$ & \multicolumn{5}{|c|}{$\begin{array}{c}\text { The value of intermediate indicators to determine } \\
\text { the adequacy of the model }\end{array}$} \\
\hline$Y$ & $Y(x)$ & $\varepsilon=Y-Y(x)$ & $\varepsilon^{2}$ & $(Y-\bar{Y})^{2}$ & $\left|\frac{\varepsilon}{Y}\right|$ \\
\hline 599.91 & 610.79 & -10.88 & 118.26 & 19881.85 & 0.018 \\
\hline 682.89 & 665.23 & 17.66 & 311.98 & 3366.67 & 0.026 \\
\hline 712.98 & 719.33 & -6.35 & 40.28 & 780.25 & 0.009 \\
\hline 715.8 & 720.01 & -4.21 & 17.71 & 630.66 & 0.006 \\
\hline 755.84 & 750.34 & 5.50 & 30.24 & 222.82 & 0.007 \\
\hline 732.97 & 734.92 & -1.95 & 3.81 & 63.09 & 0.003 \\
\hline 751.21 & 745.73 & 5.48 & 30.04 & 106.03 & 0.007 \\
\hline 797.87 & 800.62 & -2.75 & 7.54 & 3244.10 & 0.003 \\
\hline 826.47 & 831.42 & -4.95 & 24.46 & 7320 & 0.006 \\
\hline 833.19 & 830.76 & 2.43 & 5.91 & 8515.05 & 0.003 \\
\hline- & - & - & 590.23 & 44129.92 & 0.088 \\
\hline
\end{tabular}

The average approximation error is determined by the formula:

$$
A=\frac{\sum\left|\frac{\varepsilon}{Y}\right|}{n} \cdot 100 \% .
$$

For this case:

$$
A=\frac{0.088}{10} \cdot 100 \%=0.88 \% \text {. }
$$

Since the value of the average approximation error is less than $15 \%$, then it is possible to state the fact that this mathematical model is well-chosen and quite adequate.

\section{SWOT analysis of research results}

Strengths. The strengths of this research are that on the basis of representative economic indicators of the agricultural sector, key factors were identified, the regulation of which can positively affect the growth of the economic component of territorial communities.

Weaknesses. The weaknesses of this study are related to the fact that the developed mathematical model reflects the current resource potential in general and does not provide for specific steps to implement the qualitative and quantitative growth of the socio-economic aspects of the population's life. It is also worth noting that with the advent of new factors of production, it will be advisable to rethink the mathematical model with appropriate changes at the stage of presenting the correlation-regression model.

Opportunities. Additional opportunities when using the above results can influence the formation of an economically profitable strategy in the market, more efficient use of available resource balances and forecasting trends in the development of territorial communities based on economic indicators in the agricultural sector.

Threats. The developed mathematical model is based on an analysis of the existing indicators of the research area and does not pay sufficient attention to factors that will deteriorate over time without due attention: insufficient financial support for the industry, the use of outdated equipment and technologies, the lack of clear goals and strategies, and the like.

\section{Conclusions}

1. Mathematical apparatus is selected and substantiate, which allows for a comprehensive analysis of the impact of the development of the agro-industrial sector on the general economic situation of the territory of the community. As a result, a multifactorial correlation-regressive model was obtained, which in the future can be integrated into the regional administration to predict the results of the functioning of agriculture in the regions of Ukraine.

2. It is shown that the implementation of the created mathematical model will contribute to the development of agriculture in local communities. This, in turn, will become an economic locomotive that will allow communities to feel confident in regional conditions. The performed correlation-regression analysis made it possible to identify the most significant factors that determine the current opportunities for the development of agriculture in the communities of the Lviv region, namely:

- agricultural products;

- labor productivity;

- sown areas;

- investments:

- return on investment;

- transportation of goods

For the further development of issues that remain important for the communities, it should be noted the prospects for the infrastructure of rural areas of the region and ensuring sustainable development of local production. Perhaps a step is the decomposition of agricultural activities and atomic research of the organization of work on agriculture, organic production, animal husbandry, rural tourism, and the like.

\section{References}

1. Pro dobrovilne obiednannia terytorialnykh hromad (2015). Zakon Ukrainy No. 157-VIII. 05.02.2015. Available at: http://zakon2. rada.gov.ua/laws/show/157-19

2. Feldmann, A., Foschini, L. (2012). Balanced Partitions of Trees and Applications. Proceedings of the 29th International Symposium on Theoretical Aspects of Computer Science. Paris, 100-111.

3. Alzate, C., Suykens, J. A. K. (2010). Multiway Spectral Clustering with Out-of-Sample Extensions through Weighted Kernel PCA. IEEE Transactions on Pattern Analysis and Machine Intelligence, 32 (2), 335-347. doi: http://doi.org/10.1109/tpami.2008.292

4. Babaiev, V. (2013). Suchasni pidkhody do zberihannia ta naroshchennia resursnoho potentsialu terytorialnoi hromady. Publichne upravlinnia: teoriia ta praktyka, 2, 199-203. Available at: http://nbuv.gov.ua/UJRN/Pubupr 2013234

5. Slobodyanyuk, N. O., Konina, M. O. (2016). The problems of local budgets' revenues formation in conditions of financial decentralization. Ekonomka $i$ suspilstvo, 2, 611-616. Available at: https://economyandsociety.in.ua/journals/2_ukr/109.pdf

6. Krainyk, O. P. (2020). Financial stimulation of the territorial community development. Efficiency of Public Administration, 1 (62 (2)), 203-212. doi: http://doi.org/10.33990/20704011.62 .2020 .205832 
7. Borbasova, Z. N. (2020). Improvement of regional development using current and strategic territorial management mechanisms. Bulletin of the karaganda university. Economy series, 100 (4), 114-121. doi: http://doi.org/10.31489/2020ec4/114-121

8. Lonska, J. (2021). The Application of Pluralistic Territorial Development Paradigm in Assessment of Territorial State of Development: the Case Study of Latvian Regions. Regional Formation and Development Studies, 18 (1), 87-99. doi: http:// doi.org/10.15181/rfds.v18i1.1249

9. Filippetti, A., Sacchi, A. (2013). Varieties of decentralization, institutional complementarities, and economic growth: evidence in OECD countries. 54 Conferenza SIE. doi: http://doi.org/ 10.2139 /ssrn.2291053

10. Oates, W. E. (2006). On the Theory and Practice of Fiscal Decentralization. IFIR Working Paper Series, 5.

11. Thoening, J. C. (2006). Modernizing Sub-National Government in France: Institutional Creativity and Systemic Stability. State and local government reforms in France and Germany: divergence and convergence. Wiesbaden: Springer, 38-58. doi: http://doi.org/10.1007/978-3-531-90271-5_2

12. Brovina, T. (2006). Teoriya ekonomicheskogo analiza. Arkhangelsk: AGTU, 149

13. Silske, lisove ta rybne hospodarstvo. Holovne upravlinnia statystyky u Lvivskii oblasti. Available at: http://www.lv.ukrstat.gov.ua/ $\mathrm{ukr} /$ themes $/ 04 /$ theme_04.php? code $=04$
14. Publikatsiia dokumentiv Derzhavnoi Sluzhby Statystyky Ukrainy. Derzhavna statystyka Ukrainy. Available at: https://ukrstat.org/ uk/operativ/operativ2013/rp/zn_ed_reg/zn_ed_reg_u/arch_ zn ed u.htm

15. Orlova, I., Polovnikov, V. (2011). Ekonomiko-matematicheskie metody i modeli: kompyuternoe modelirovanie. Moscow: Vuzovskiy uchebnik, 389.

16. Tsehelyk, H. (2011). Osnovy ekonometrii. Lviv: LNU imeni Ivana Franka, 133.

17. Kovalova, I. L. et. al. (2019). Ekonometriia. Odessa: ODABA, 423.

Roman Bihun, Postgraduate Student, Department of Information Systems and Networks, Lviv Polytechnic National University, Lviv, Ukraine, e-mail: bigunroman@ukr.net, ORCID: https://orcid.org/ 0000-0003-4363-4532

Vasyl Lytoyn, Doctor of Technical Sciences, Professor, Department of Information Systems and Networks, Lviv Polytechnic National University, Lviv, Ukraine, e-mail: vasyl17.lytoyn@gmail.com, ORCID: https://orcid.org/0000-0002-9676-0180

Nazar Oleksiv, Department of Information Systems and Networks, Lviv Polytechnic National University, Lviv, Ukraine, e-mail: naoleksiv@gmail.com,ORCID: https://orcid.org/0000-0001-7821-3522 